\title{
FIDIC Sözleşmeleri'ndeki Yeniliklerin Değerlendirilmesi ve Eski Versiyonlarla Karşılaştırılması
}

\author{
Nur BALKANLI ERYİĞiT ${ }^{1 \mathrm{a}}$, Betül YAYLAN SEVIMLi ${ }^{1 \mathrm{~b}}$, Gürkan Emre GÜRCANLI ${ }^{2 \mathrm{c}}$, Senem BíLİR ${ }^{2 \mathrm{~d} *}$ \\ ${ }^{1}$ İstanbul Teknik Üniversitesi, Mimarlık Fakültesi, İnşaat Projeleri Yönetimi Ana Bilim Dalı, İstanbul/Türkiye \\ ${ }^{2}$ İstanbul Teknik Üniversitesi, İnşaat Fakültesi, İnşaat Mühendisliği Bölümü İstanbul/Türkiye \\ sbilir@itu.edu.tr
}

Received/Geliş: 26.11 .2020

Accepted/Kabul: 29.12.2020

Öz: Uluslararası ilişkilerin en fazla görüldüğü sektörlerden biri inşaat sektörüdür. Sektörün heterojen ve karmaşık yapısı düşünüldüğünde, inşaat projelerinin hedeflenen maliyet, süre ve kalitede tamamlanması son derece önemlidir. Bu noktada, proje yönetiminin alt başlıklarından sözleşme idaresinin profesyonel olarak yapılması gerekmektedir. İyi bir sözleşme idaresi ise ancak, doğru ve meslek profesyonelleri tarafindan hazırlanmış nitelikli bir inşaat sözleşmesiyle mümkün olabilir. Günümüz ekonomik koşulları düşünüldügünde, nitelikli bir yapım projesinin maliyetinin ön görülen maliyet sınırları içerisinde kalması ve tarafların arasında ilişkilerin korunması, uluslararası standartlarda hazırlanmış sözleşmeyle gerçekleşebilir. Ülkemizde ve dünya ülkelerinde, farklı standartta hazırlanmış farklı uluslararası sözleşme taslakları kullanılmaktadır. Ülkemizde ve Avrupa ülkelerinde daha çok FIDIC standart sözleşme taslaklarıyla yapılmış inşaat projeleri görmek mümkündür. Bu çalışmayla birlikte FIDIC Sarı Kitap ve Kırmızı Kitap sözleşme formlarının 1999 ve 2017 versiyonları arasındaki farklılıklar karşılaştırılarak, söz konusu iki versiyon arasındaki gelişmeler ve iyileştirmeler sunulmaktadır.

Anahtar Kelimeler: Sözleşme standartları, uluslararası inşaat sözleşmeleri, FIDIC-Sarı Kitap, FIDIC-Kırmızı Kitap

\section{Evaluation of the Improvements in FIDIC Contracts and Comparison with Older Versions}

\begin{abstract}
Construction industry is the one of the most common sectors of internationalization. By taking into account the complex and heterogeneous structure of the construction industry, it is crucial to complete the construction projects, within the targeted cost, time and quality. Therefore, the construction administration, one of the subtitles of the construction project management, should be performed professionally. However, appropriate and satisfactory construction administration is just possible with the right and qualified contract, elaborated by the experts in the field. In addition, under today's economic circumstances, keeping the total construction cost within the estimated cost boundaries of the qualified construction project, just directly related with the contract, prepared under the guidance of an international contract standard form. Many different international contract forms are used in all around the world but most common one is FIDIC Standard Contracts that have been used in Turkey and European Union countries for years. This research paper aims to investigate and evaluate the improvements and developments in FIDIC Standard Contracts and compare Yellow and Red Books 1999 and 2017 versions from the point of construction management principles and body of knowledge.
\end{abstract}

Keywords: Contract standards, international construction contracts, FIDIC Yellow Book, FIDIC Red Book

\section{Giriş}

Birçok farklı iş ortağının aynı anda ve aynı mekanda üretim yapmak zorunda olduğu inşaat sektöründe projelerin etkin bir şekilde yönetimi çok önemlidir [1]. Bu sebeple, sözleşme idaresi 
konusunda özellikle dikkatli olunmalıdır. Uluslararası İnşaat Sözleşmeleri arasında en yaygın kullanımı olan Müşavir Mühendisler Milletlerarası Federasyonu (International Federation of Consulting Engineers, FIDIC) Standart İnşaat Sözleşmeleri, dünya çapında inşaat sektörüne yön veren belgeler arasındadır. Genel olarak, FIDIC sözleşmeleri, etkin sözleşmeler yapabilmek ve bilinmeyen sözleşme hükümleri için mali yükümlülükleri azaltmak amacıyla geliştirilmiştir [2,3,4]. FIDIC standart sözleşmelerinin ilk baskısı özellikle uluslararası inşaat projelerinde kullanılmak üzere 1957'de yayınlanmıştır [5]. İkinci baskı 1963'te, üçüncüsü ise 1977'de yayınlanmıştır. Zaman içinde birçok değişiklik yapılmış [4] ancak 1999 yılında FIDIC, yeni standart sözleşme paketi olarak bilinen "FIDIC 99" u yayınlamıştır.

Öncelikle inşaat proje tedarik (veya yüklenici tarafından bakılınca teslim) sistemlerinden en yaygın olan Tasarla-İhale et-İnşa et ve Tasarla-İnşa et yöntemlerinden ve aralarındaki farklardan söz etmekte yarar bulunmaktadır. Bu konuda hala en temel kitaplardan birisi olan kitaplarında Sanvido ve Konchar (1999) bir projede başarıya ulaşmak içen gerekli bir sözleşme "organizasyonları birtakım olarak davranmaya cesaretlendiren ve ödüllendiren" bir sözleşmedir diyerek, proje teslim veya tedarik yönteminin altını çizmektedir [6]. Burada pek çok yazarın da altını çizdiği üzere geleneksel Tasarla-İhale et-İnşa et yöntemi geleneksel, doğrusal, taraflar arasında bir takım çalışmasına en az uygun proje teslim yöntemi olmakta ve bu yüzden de bu türden taraflar arası ilişkileri düzenleyen FIDIC Kırmızı Kitap'ı bilmek ve yönetmek önem kazanmaktadır. Örneğin, Katar dahil Orta Doğu projelerinin çoğunda, FIDIC Kırmızı Kitap tercih sözleşmesi olmaya devam etmektedir [7,8]. Birçok yayında belirtildiği gibi sarı ve kırmızı kitap uluslararası en yaygın benimsenen sözleşme formudur [9,10]. Sanni ve diğerleri (2020), çalışmalarında sözleşme idaresi için en yaygın olarak kullanılan FIDIC paketinin, birçok işveren ve müteahhit tarafından herhangi bir yeni inşaat sözleşmesi için başlangıç noktası olarak kabul edilen Kırmızı Kitap olduğunu belirtmişlerdir [11].

Literatür araştırıldığında FIDIC 2017 ile getirilen yeniliklerin bazı çalışmalarda kısmen incelendiğine rastlanmış ancak bir bütün olarak FIDIC 2017'nin incelendiği ve FIDIC 99 ile kıyaslandığı bir çalışmaya rastlanmamıştır [2,12,13]. FIDIC sözleşmeleri yapısı gereği inşaat proje yönetiminin bir alt başlığı olan Sözleşme İdaresi ilkeleriyle de uyumludur. Ancak maalesef, ülkemizde FIDIC Standart Sözleşme belgeleri konusunda uzman sayısı az olup, özellikle uluslararası inşaat projelerinde bunun etkisi hissedilmektedir. Ayrıca, kamu inşaat projelerine yönelik çalışmanın azlığı bu makale çalışmasının çıkış noktası olmuştur.

$\mathrm{Bu}$ makalede, geleneksel inşaat tedarik sistemlerinde (Tasarla-İhale Et-İnşa Et) kullanılan Kırmızı Kitap ve daha çok endüstriyel yapıların ve tesislerin inşasında kullanılan (Tasarla-İnşa Et) Sarı Kitap 1999 ve 2017 versiyonları, inşaat proje yönetimi bakış açısıyla karşılaştırılmıştır. Halen ülkemizde 2017 versiyonları ile imzalanmış bir proje bulunmamasından dolayı, makalenin inşaat sektöründe çalışan profesyoneller için iyi bir başvuru kaynağı olacağı düşünülmektedir. Bu amaçla, çalışma kapsamında FIDIC Sarı ve Kırmızı Kitap' in genel şartları tek tek irdelenmiş ve farklılıklar tespit edilmiş olup, bu yayında, kitabın her iki versiyonlarında daha major etkiye sahip değişikliklere yer verilmiştir. Herhangi bir değişiklik yapılmayan FIDIC Gri Kitap, bu çalışma kapsamı dışında yer almaktadır. Bunların yanında, FIDIC sözleşmelerinde kullanılan bazı terimlerin Türkçe karşılıklarının oluşturulması hedeflenmiştir.

\section{FIDIC Tip Şartnameleri Sarı ve Kırmızı Kitap 2017 Versiyonlarının Getirdiği Yenilikler}

Bu bölümde incelenen her iki kitaptaki bazı kavramlar ve yenilikler, standart madde sıralarına göre incelenecektir. Öncelikle Mühendis ve Yüklenici kavramlarındaki yenilikler irdelenecek, ardından bir inşaat projesinde karşılaşılacak sorunlara ve bunların taraflarca yönetilmesine/çözüme kavuşturulmasına yardımcı olacak maddeler sırasıyla incelenecektir. 


\subsection{Mühendis Kavramı}

Sarı ve Kırmızı Kitapta temel bir yeri olan Mühendis (The Engineer) kavramı her iki kitapta da madde 3.'te ele alınmaktadır. FIDIC Genel Hükümler bölümü, mühendisi şöyle tanımlamıştır: "İşveren tarafından sözleşme amaçları için mühendis olarak hareket etmek üzere sözleşmede adı geçen kişi anlamına gelir" İşveren, sözleşmede belirtilen mühendislik görevini yerine getirecek kişiyi tayin eder. Atanan kişi sözleşme kapsamındaki tüm yetkiye sahip olur. Mühendis tüzel kişi ise, mühendis tarafından istihdam edilen gerçek bir kişi, sözleşme uyarınca mühendis adına hareket etmek üzere atanır ve yetkilendirilir. Aşağıda 2017 yılındaki yeniliklerin neler olduğu anlatılmıştır.

3.1 [Mühendis] maddesinde, mühendisin görev ve yetkileri ve sahip olması gereken teknik özellikler açıkça tanımlanmıştır. Buna göre Mühendis; Birey veya tüzel kişilik olabilir, uygun niteliklere, deneyime ve yeterliliğe sahip profesyonel bir mühendis olmalıdır ve 1.4 [Yasa ve Sözleşme Dili] maddesinde belirtilen yasa ve sözleşme dili gerekliliklerine sahip, konusunda profesyonel bir meslek adamı olmak zorundadır. Mühendis tüzel kişi ise, Mühendis adına görevlendirilen ve yetkilendirilen gerçek kişi, taraflara ihbarda bulunacaktır. Yetki, bu ihbar her iki tarafça alınana kadar yürürlüğe girmeyecektir. İnşaat süresince İşveren vekili olarak çalışır; İşveren adına karar verir, sunum yapar, onay verir, belge düzenler, taraflara ihbar bildiriminde bulunabilir.

FIDIC 2017 baskısında Mühendis, Mühendis temsilcisi atayabilir ve ona, Mühendis adına sahada çalışması için gereken yetkiyi 3.4 [Mühendisin Yetki Devri] maddesi uyarınca devredebilir. Mühendis Temsilcisi işlerin sahada yürütüldügü süre boyunca sahada bulunacaktır. İşin yürütülmesi sırasında Mühendis temsilcisinin geçici olarak sahadan ayrılması durumunda, Mühendis eşdeğer, deneyimli ve yetkin bir yedek atayacaktır ve bu değişimi Yüklenici' ye ihbar edecektir. Mühendis, Madde 3.7 [Anlaşma ve Tespit Yetkisi] alt maddesi uyarınca hareket etme ve/veya 15.1 [Düzeltme Bildirimi] maddesine göre bir düzeltme ihbarı yayınlama yetkisini devredemez. Yüklenici, bir temsilci tarafından verilen herhangi bir talimatı veya ihbarı sorgularsa, Yüklenici bir İhbar vererek konuyu Mühendise havale edebilir. Mühendis, Yüklenici' nin bildirimini aldıktan sonraki 7 gün içinde, temsilcisinin talimatını veya ihbarı tersine çevirerek veya değiştirerek yanıt vermezse, temsilcinin talimatını veya notunu onaylamış sayılır.

Tüm bu rollerin yanı sıra 2017 baskısıyla birlikte, 3.7 [Anlaşma ve Tespit Yetkisi] maddesinde, Mühendis' e tarafsız karar verme görevi de yüklenmiştir ve İşveren' in rızası olmadan, Mühendis' in adil kararlar vermesi beklenir. Ayrıca 2017 baskısı 3.7.1 [Anlaşmaya varmak için danışma] Maddesi istişare kavramını ortaya koymaktadır. Mühendis' in her iki tarafla ortaklaşa veya ayrı ayrı görüşmesi ve anlaşmaya varılması için bir tartışmayı teşvik etmesi gerekmektedir. Mühendis her iki tarafta da istişarenin kaydını tutacak ve eğer bir anlaşmaya varılırsa, 3.7.3 [Belirli Süre] Maddesinde belirtilen sürelerde Mühendisin "Anlaşma Bildirimi” olduğunu belirten bir ihbarda bulunması ve sözleşmenin bir kopyasını içermesi ve iki tarafça da imzalanması gerekmektedir.

3.7.3 [Belirli Süre] maddesine göre, anlaşma bildirimi 42 gün içinde veya Mühendis tarafindan önerilebilecek ve her iki tarafça da kabul edilebilecek diğer süre dahilinde verilmelidir. Anlaşmanın sağlanamadığı durumlarda, Mühendis 42 günlük bir karar süresine daha sahiptir. Sonuç itibariyle, Mühendis 84 günlük bir süre içerisinde sözleşme şartlarına uyumlu adil bir karar vermek durumundadır. Taraflardan biri Mühendis' in verdiği karara uymuyorsa, 28 gün içerisinde karar için "Memnuniyetsizlik Bildirimi”" nde bulunur ve Uyuşmazlıktan Kaçınma ve Çözüm Kurulu (Dispute Adjudication Boards, DAB)' na başvurur. 28 gün içerisinde başvuru yapılmaz ise, Mühendis' in kararı DAB görev alana kadar bağlayıcı ve geçerli olur.

Yeni eklenen 3.8 [Toplantılar] maddesinde, Mühendis başkanlığında yapılacak yönetim toplantıları, bu toplantılara katılacak taraflar belirtilmektedir. Toplantı kayıtlarının tutulması ve saklanması 
mühendis yükümlülüğünde olup, kayıtlar toplantı tarafları ve İşveren' e mühendis tarafindan sunulur.

\subsection{Yüklenici Kavramındaki Yenilikler}

Sarı ve Kırmızı Kitapta temel bir yeri olan Yüklenici kavramı her iki kitapta da madde 4.'te ele alınmaktadır. Aşağıda 2017 yılında yayınlanan kitaplarda getirilen yeniliklerden bahsedilmektedir. 1999 baskısında var olan 4.20 [İşveren Tarafindan Temin Edilen Malzemeler ve İşveren Ekipmanları] maddesi 2017 baskısında, Yüklenici ana başlığı altından çıkarılarak, belli kapsam değişiklikleriyle birlikte, 2.6 [İşveren Tarafından Temin Edilen Malzemeler ve İşveren Ekipmanları] maddesi olarak İşveren başlığı altına eklenmiştir. 2017 basımında Yüklenici' nin yetki kapsamı daha net ve açık ifadelerle geliştirilmiş, olası belirsizlik ve uyuşmazlıklara sebebiyet vermeyecek şekilde düzenlenmiştir.

2017 baskısında yer alan 4.8 [Sağlık ve Güvenlik Yükümlülükleri] maddesinin güncel haliyle, proje yönetim aracı olarak sağlık ve güvenlik yükümlülüklerinin önemine vurgu yapılmaktadır. Bir önceki baskıda yer alan 4.8 [Güvenlik Prosedürleri] maddesi, personel sağlığı açıklamalarından yoksun sadece 5 alt başlıkta hazırlamış bir paragraflık bir açıklama iken, yeni yapılan düzenlemeyle daha kapsamlı her iki tarafinda yükümlüklerini düzenler hale getirilmiştir. Yeni baskıda yer alan, 4.8 [Sağlık ve Güvenlik Yükümlülükleri] maddesinin revizesiyle birlikte, Yüklenici' nin inşaat süresi boyunca, işin sağlık ve güvenlik kriterlerinin sağlanması için önlemler alması, olası kazaların ve bu kazalar nedeniyle yaşanacak olumsuzlukların önüne geçmesi istenmektedir. 1999 baskısında, 4.8 [Güvenlik Prosedürleri] maddede sağlık ve güvenlik personeline atıfta bulunulmazken, 2017 baskısında sağlık ve güvenlik yöneticisine yer verilerek, söz konusu sistem düzenlemelerinin, ilgili kişiyle yapılması beklenmektedir.

2017 basımıyla birlikte, 1999 basımdaki 4.9 [Kalite Güvencesi] maddesinin kapsam ve niteliği geliştirilmiş, madde ismi 4.9 [Kalite. Yönetim ve Uygunluk Doğrulama Sistemleri] olarak değiştirilmiştir. Söz konusu madde içeriğine göre, Yüklenici, inşaat projesi için kalite yönetim sistemi (QMS) ve uygunluk doğrulama sistemi (CVS) hazırlayacaktır. Yüklenici, kalite yönetim sisteminin (QMS) kontrol ve denetimlerini Mühendis ile birlikte yapacak ve Mühendise kabul edilebilir bir şekilde ve eksiksiz bir uygunluk doğrulama (CVS) kayıtları sunacaktır. Yapılan yeni düzenlemeyle birlikte FIDIC tarafından, proje yönetim ve sözleşme idaresi aracı olarak, kalite yönetimine verilen önemin arttığı açıkça görülmektedir.

1999 FIDIC' te yer almayıp, 2017 baskısında yer alan 13. [Değişiklikler ve Düzeltmeler] maddesine uyarınca, işin bedelinde ortaya çıkabilecek olası artış ve azalışların, sözleşme bedelinin toplam \%20 sinden fazla olması durumunda, İşveren Yüklenici' den bu orana denk gelecek şekilde, kati teminat bedelinde artış ve Yüklenici yararına değişiklik talep edebilir. Ek olarak, 15.5 [İşveren Yararına Fesih], [16.2 Yüklenici Tarafından Fesih], 18.5 [İsteğe Bağlı Fesih] veya 18.6 [Yasal Hükümlere Göre Performans Yükümlülüğünün Ortadan Kalkması] maddelerinin ortaya çıkması durumunda, "feshin yapıldığı tarih itibariyle kati teminat iadesi acilen yapılmalıdır" ifadesi yer almaktadır.

4.18 [Çevrenin Korunması] maddesinde, Yüklenici' nin çevrenin korunması için alması gereken önlemler arasına "proje yapılacak bölgede için yapılmış çevre etki değerlendirme raporu varsa, bu rapora uyulmak zorundadır "ifadesi eklenmiştir. 4.19 [Geçici Alt Yapı Hizmetleri] maddesinde, bir önceki baskıda yer alan 4.19 Elektrik, Su, Gaz maddesinin alt başlıklarından farklı olarak, iletişim altyapısı kullanımından da bahsedilmiştir. Bir önceki baskıdan farklı olarak, söz konusu altyapı hizmet kullanım ödemelerinin Yüklenici tarafından yapılacağı ve ödeme yapılacak periyodlar, net bir şekilde ifade edilmiştir.

4.20 [İlerleme Raporu] maddesine göre, eski baskıdaki halinden farklı olarak, raporun teslim şekliyle ilgili kapsamlı ifadelere yer verilmiştir. Buna göre, rapor teslimi, 1999 baskısında ifade 
edildiği gibi Yüklenici tarafından 6 kopya hazırlanarak mühendise teslim edilmeyecektir. İlerleme raporu, 1 orijinal kopya, 1 dijital kopya ve sözleşmede belirtildiyse, sözleşmede belirtilen adet ve formatlarda ek kopya olarak Mühendis' e teslim edilecektir.

\subsection{Isșe Bașlama, Gecikmeler ve İșin Durdurulması Konusundaki Yenilikler}

FIDIC 2017 ile işe başlama, gecikmeler ve işin durdurulması hususunda getirilen yenilikler aşağıda sunulmaktadır. 2017 baskısında, 8.3 [İş Programı] maddesinin alt başlıklar sayısı fazlalaştırılarak, daha nitelikli, her aktivite için en erken ve en geç başlangıç, bitiş tarihlerinin, bollukların ve kritik yolun belirtildiği, mantıksal bir ilişki içerisinde kurgulanmış iş programın gerekliliğine açıkça vurgu yapılmaktadır. İlk defa 2017 baskısı, her bir tarafin diğerine "Bilinen veya muhtemel gelecekteki olayların öncesinde tavsiyede bulunmasını gerektiren önceden uyarı hükümlerini” sunar. Söz konusu maddeyle, inşaat sırasında ortaya çıkabilecek olası olumsuz bir durum ve uyuşmazlığa sebebiyet verebilecek olayların, ilk aşamadan önüne geçilmesi amaçlanmaktadır. Sözleşme bedelindeki artış, iş programında yaşanacak gecikmeler ve işin performansını olumsuz yönde etkileyecek aktivitelerin önlenmesi, söz konusu maddeyle amaçlanan başlıca durumlardır.

2017 baskısında yer alan 8.4 [Tarafların Birbirini Erkenden Uyarması] maddesiyle birlikte, inşaat sırasında ortaya çıkabilecek durumlar aşağıdaki gibidir;

- Yüklenici personelinin işini olumsuz etkileyebilecek durumlar

- İşlerin tamamlandığında performanslarını olumsuz etkileyebilecek durumlar

- Sözleşme fiyatını arttırabilecek ve/veya

- İşin veya bir bölümün ilerlemesinde gecikmeye sebep olabilecek durumlar

Önceden bir uyarı vermek için zaman sınırı ve bir yaptırım yoktur. Tarafların birbirini erkenden uyarmasını gerektirecek bir durum ortaya çıktığında, durum Mühendis tarafından Yüklenici' ye iletilecektir. 13.3.3 [Teklif Talebine Göre Değişiklik] maddesine istinaden, iletilen durumla ilgili değişiklik yapılarak, olası bir olumsuzluğun önlenmesi sağlanacaktır. "Gecikme zararı" 2017 baskılarında yeni tanımlanmış bir terimdir. 8.8 [Gecikme Zararları] maddesi, gecikme zararlarının, 8.2 [Tamamlanma Süresi] maddesi belirtilen şekilde tamamlanma süresi ile işlerin veya bölümlerin bitiş tarihi arasında geçen her gün için ödenecek olan ve sözleşme verilerinde belirtilen tutardır. Taraflar, Madde 8.8 [Gecikme Zararları] ile ilgili sözleşme verilerinde, İşveren' nin sözleşmeyi feshetme hakkına sahip olduğu azami gecikme zararı tutarını belirtebilirler.

\section{4. İșin Devralınmasından Sonra Ortaya Çıkan Kusurlar Hakkında Getirilen Yenilikler}

İşin Devralınmasından Sonra Ortaya Çıkan Kusurlar konusu FIDIC 99'da ve FIDIC 2017'de madde 11 kapsamında işlenmiştir. 1999 basımında Kusurlu İşler Sorumluluğu başlığıyla var olan 11. Madde, 2017 basımında İş Devralınmasından Sonra Ortaya Çıkan Kusurlar olarak revize edilmiştir. 11.1 [Eksik İşlerin Tamamlanması ve Kusurların Giderilmesi] alt başlığında, olası bir kusur ve hatanın kusur ihbar süresinde (DNP) ortaya çıkması durumunda taraflarca izlenmesi gereken yol, alt başlıklarla detaylı bir şekilde ifade edilmiştir. 7.5 [Kusurlu İmalatlar ve Reddetme] maddesine göre, Mühendis, Yüklenici tarafından yapılan öneriyi reddedebilir. Bu durumda, Yüklenici önerisini revize ederek tekrar sunar.

Kusurlu imalatların giderilmesi sonrasında yapılacak testler ve bu testler sırasında ortaya çıkan her türlü maliyet Yüklenici' ye aittir. Bu testlerin yapılması sırasında İşveren' e ek maliyet ortaya çıkıyorsa, İşveren söz konusu maliyetlerin karşılanması için 20.2 [Ödeme ve Süre Uzatımı Hak Talepleri] maddesine göre hak talebinde bulunabilir.

2017 basımında, 11.3 [Kusurların İhbar Süresinin Uzatılması] maddesine göre, bu sürenin uzatılması konusuna sınırlandırma getirilmiştir. Söz konusu sürenin uzatımı için 2 yıldan daha fazla 
bir uzatmanın verilemeyeceği her iki baskıda da yer almakla birlikte, sürenin, sözleşmede yer alan hata bildirim süresinin (DNP) sona ermesiyle başlayacağı açıkça ifade edilmiştir.11.7 [İşin Devralınmasından Sonra Erişim Hakkı] maddesi, 2017 baskısında, eski baskıdan farklı olarak, yüklenicinin işin devralınmasındaki sonraki erişim hakkı, kati teminat verildikten sonraki 28 günlük süreyle sınırlandırılmış ve erişim talebi süreci kapsamlı bir şekilde ifade edilmiştir. İşverenin şantiye sahasına ve iş kayıtlarına erişim hakkı için izin vermesiyle alakalı yaşanacak olası bir gecikmede, yüklenici adına ekstra bir maliyet oluşuyorsa, yüklenici 20.2 [Ödeme ve Süre Uzatımı İçin Hak Talepleri] maddesine istinaden hak talebinde bulunabilir. 11.9 [Performans Sertifikası] maddesinde, performans sertifikasının Yüklenici' ye verildikten sonra, bir kopyasının İşveren' e ve 1999 basımdan farklı olarak, bir kopyasının da DAB' a verilmesi gerekliliğinden bahsedilmektedir.

\subsection{Değişiklikler ve Düzeltmeler Başlıklarında Getirilen Yenilikler}

Madde 13'te ise Değişiklikler ve Düzeltmeler Başlıklarında Getirilen Yenilikler konusu ele alınmıştır. FIDIC 2017'de Değişiklikler ve Düzeltmeler Başlıklarında Getirilen Yenilikler konusunda getirilen yenilikler şu şekildedir. 13.3.1 [Talimatla Değişiklik] maddesine göre Yüklenici, Mühendis' in değişiklik talimatına bir öneri sunarak cevap verebilir. Yüklenici' nin değişiklik talimatına gerekçeleriyle öneri sunması için "28 gün ya da Yüklenici tarafından önerilen ve de Mühendis tarafından kabul edilen herhangi bir tarih "ifadesiyle zaman sınırlandırılması getirilmiştir. Mühendis Yüklenici’ den söz konusu öneri için, işin kaynak ve yöntemlerini açıklayan ayrıntılı bilgilerinin sunulmasını ister. Buna göre yüklenici önerisinde,

- Değişikliğin uygulanması için bir iş programı

- İş programının ve işin tamamlanma zamanının değiştirilmesi için öneri

- Destekleyici ayrıntılarla sözleşme fiyatını değiştirmek için öneri

- Ortaya çıkacak ya da çıkabilecek maliyetlerle ilgili, açıklayıcı bilgileri içeren önerisini mühendis' e sunabilir.

13.3.1 [Talimatla Değişiklik] maddesinde yüklenici tarafindan yapılan öneri, herhangi bir süre uzatımına ve sözleşme bedelinde ve ödeme planında değişikliğe, sebebiyet verip vermemesine göre, Mühendis tarafından 3.7 [Anlaşma ve Tespit Yetkisi] maddesine kapsamında değerlendirilir ve yükleniciye cevap verilir. 13.3.2 [Teklif Talebine Göre Değişiklik] maddesine göre, bir önceki basımdan farklı olarak, Yüklenici' nin teklif talebi ihbarına rıza gösterip göstermemesi durumunda ortaya çıkacak durumlar açıklanmıştır. Buna göre Mühendis, Yüklenici’ nin teklif talebine rıza göstermez ve talebi reddederse ve bu öneri sonucunda Yüklenici adına ekstra bir maliyet oluşursa, Yüklenici 20.2 [Ödeme ve Süre Uzatımı Hak Talepleri] maddesine istinaden hak talebinde bulunabilir.

\subsection{Sözleşme Bedeli ve Ödemeler Konusunda Getirilen Yenilikler}

Mühendis' e teslim edilecek hakediş çizelgesinde yer alan bedelin içeriğiyle ilgili 4 yeni alt madde eklenmiştir. Bu maddelerde, 13.4 Geçici Meblağ, 14.9 Nakit Teminat Kesintilerinin İadesi, 4.19 Geçici Altyapı Hizmetleri maddeleriyle ilişkilendirilen ve daha önce ödeme sertifikalarında kesinti yapılan tüm miktarlar açıkça ifade edilmiştir. 14.6 [Ara Ödeme (Hakediş) Sertifikası] maddesinde belirtildiği üzere, 3.5 maddesine istinaden, Mühendis tarafından her iki tarafi da koruyacak şekilde adil, bağlayıcı bir karar vermesi beklenir. Yüklenici' nin 20.2 [Ödeme ve/veya EOT Alacakları] uyarınca Son Ödeme Sertifikasına (FPC- Final Payment Sertificate) itiraz etmesi için yalnızca 56 günü vardır. Aksi takdirde, Yüklenici bu tutarları kabul etmiş sayılır ve İşveren başka bir sorumluluk üstlenmez.

\section{7. İşveren Tarafından Fesih Konusundaki Yenilikler}

Değer tespiti için 3.7 [Mühendis' in Anlaşma ve Tespit Yetkisi] maddesine göre işlem yapılır. 2017 basımında bir önceki basımdan farklı olarak, değer içeriği belirlenirken, 14.13 [Kesin Ödeme 
Sertifikasının Verilmesi] maddesinde yer alan tanımlamaların referans alınması gerekliliği ve Yüklenici tarafından tamamlanmış işlerin, belgelerini malzemelerin ve tesislerin bu değer içerisine dahil edilmemesi gerekliliği belirtilmiștir. 2017 basımında, fesihle ilgili tüm değerlendirmeler yapılıp, taraflarca üzerinde anlaşma sağlandıktan ve Yüklenici tarafından kabul bildirimi Mühendis' e ibra edildikten sonra, 112 gün içerisinde hesaplanan bedel İşveren tarafindan Yüklenici' ye ödenmelidir.

\subsection{Yüklenici Tarafından Fesih ve İşin Durdurulması Konusunda Getirilen Yenilikler}

2017 FIDIC baskısında 16.1 [Yüklenici Tarafından İşin Durdurulmasının] nedenleri arttırılmış, aşağıdaki nedenler eklenmiştir. İşveren tarafından, Mühendis' in 3.7 [Anlaşma ve Tespit Yetkisi] maddesine göre, Mühendis tarafından yapılan bağlayıcı anlaşma ya da tespitlere ve 21.4 [DAB Kararının Geçerli Olması] maddesi gereğince DAB tarafından verilen kararlara, uyulmuyorsa Yüklenici sözleşmeyi ihbar yayınlayarak işi durdurabilir.

2017 baskısının 16.1 maddesinde, 'Yüklenici' nin İşveren' e işin durulmasına sebep olan nedenleri içeren ihbarı vermesinden sonra ve fesih ihbarından önce, İşveren ilgili olumsuz durumları ortadan kaldırıyorsa Yüklenici' nin işe devam edecektir" açıklaması yer almaktadır. 2017 baskısı ayrıca 16.2 [Yüklenici Tarafından Fesih] maddesi ile Yüklenici’ ye feshetme hakkı veren birkaç yeni gerekçe de getirmiştir;

- Mühendis' in 3.7 [Anlaşma ve Tespit Yetkisi] maddesi uyarınca belirlenmesine veya DAB' in bir kararına uyulmaması ve böyle bir başarısızlık,

- Yüklenici tarafından 8.1 [İşin Başlaması] maddesi uyarınca kabul mektubunun alınmasından sonraki 84 gün içinde teslim alınmaması durumunda ve

- İşveren' in, makul kanıtlara dayanarak, herhangi bir zamanda işlerle veya sözleşmeyle ilgili olarak hileli veya zorlayıcı bir uygulamada bulunduğu tespit edilmişse yüklenici tarafından fesih gerçekleştirilebilir.

\section{9. İşveren ve Yüklenicinin Hak Talepleri Hususlarında Yenilikler}

2017 baskısında hak talepleri, 20 [İşveren ve Yüklenici’ nin Hak Talepleri] isimli ayrı bir ana başlık altında irdelenmiş olup her iki Taraf da aynı prosedür ve yükümlülüklere tabidir. Mühendis, 20.2 [Ödeme ve Süre Uzatımı Hak Talepleri] maddesine göre, hak taleplerini İşveren adına alır, hak talebini reddeder, onaylar ya da taraflar arasında orta yolu bulabilmek adına önerilerde bulunur.

Madde 20 [İşveren ve Yüklenici' nin Hak Talepleri]; İşveren Alacakları, Yüklenici talepleri "İşveren ve/veya süre uzatımından ek ödeme" ve Taraflardan biri "(a) ve (b) hariç başka bir (her ne olursa olsun) hak veya tazminat." için bir prosedür belirler. Özellikle, talepleri bildirmek için talebi doğuran olay veya durumun farkına varılması durumundan en geç 28 gün içindeki ihbar yükümlülüğünü 2017 baskısında İşveren için de geçerlidir. Mühendis, talep sahibinin 28 günlük süre içerisinde talep bildirimini veremediğini ve geç bildirim yaptığını düşünürse, talebi aldıktan sonraki 14 gün içerisinde bir ihbar yayınlar. Talep sahibini geç başvuruyla ilgili uyarma konusunda yeni bir pozitif zorunluluk vardır ve bu durumda talebi yapan taraftan bu ihbarın gecikmesinin nedenlerini açıklamasını ister. Ek olarak, 2017 baskısında, "tamamen ayrıntılı bir hak talebi" nin ne anlama geldiği açıklanmaya çalışılmıştır. Mühendis' in 14 gün içerisinde, geç başvuruyla ilgili ihbarı karşı tarafa iletmesi durumunda, ilgili taraftan geç başvuruyla ilgili 20.2.4. [Tam Detaylı Hak Talebi] maddesine göre gecikme nedenleri için tatmin edici ve detaylı bir açıklama ister. Tam detaylı hak talebinde; talebi doğuran olayın veya durumun ayrıntılı bir açıklaması, talebin sözleşmeye dayalı ve/veya diğer yasal dayanağı hakkında açıklama, talep eden tarafın dayanağı olan tüm güncel kayıtlar ve ekstra ödeme, süre uzatımı talebi ve İhbar bildirim süresi uzatımıyla ilgili destekleyici belgeler yer alır. 


\subsection{Uyuşmazlıklar ve Tahkim Konusundaki Yenilikler}

DAB üyeleri sözleşme süresince, şantiye sahasına belli zamanlarda ziyaretler yaparak, olası fiziki problemleri tespit eder ve mühendise bildirir. Bu yöntemle olası uyuşmazlıkların oluşmadan önüne geçilmeye çalışılır. Enformal bir süreç olması sebebiyle, taraflar DAB tarafindan yapılan uyarı ve tavsiyelere uymak zorunda değillerdir.

21.3 [Uyuşmazlıklardan Kaçınma] maddesine göre, taraflar uyuşmazlığa sebep olacak ya da teknik, uzman bir kişinin bilgisine ihtiyaç duyulan olası bir durumu fark ettiğinde, taraflar kendi aralarında anlaşarak, gayri resmi destek talebiyle DAB' a başvurabilirler. Söz konusu destek talebi, Mühendis' in 3.7. [Anlaşma ve Tespit Yetkisi] maddesindeki görevlerini engellemeyecek şekilde, Mühendis tarafından yapılır. DAB talebi kabul ederse, söz konusu görüşmeler belli toplantı ya da saha ziyareti günlerinde yapılabilir.

Diğer bir değişiklik ise zaman planı açısından yapılmıştır;

- DAB, başvuruyu aldıktan sonra 84 gün içinde karar vermelidir;

- Bir Taraf, Mühendis' in kararıyla bir Memnuniyetsizlik İhbarı verdikten veya aldıktan sonra 42 gün içinde DAB' a bir Uyuşmazlık bildirmelidir.

- DAB' in kararından memnun olmayan bir Tarafın diğerine 28 gün içinde "Memnuniyetsizlik İhbarı" (NOD) vermesi gerekir, aksi takdirde karar kesinleşir ve her iki taraf için de bağlayıcı olur.

Her ne kadar FIDIC, DAB tarafindan uygulanacak bir uyuşmazlık çözümünü desteklese de tahkime başvurmak için dört yol sunar: NOD verilmesi ardından dostane çözümlerin geçerli olmadığı (21.5 Maddesi), DAB' in kararına uyulmaması (Madde 21.7), Mühendis' in bağlayıcı ve nihai tespitine uyulmaması veya kararlarının tatmin edici olmadığı (Madde 3.7.5) ve DAB' in yerinde olmaması (Madde 21.8) durumlarında, taraflar uluslararası tahkime başvurabilirler.

\section{2017 FIDIC Sarı ve Kırmızı kitapların 1999 FIDIC Sarı ve Kırmızı Kitap ile Karşılaştırılması}

FIDIC 1999 Kırmızı kitap yaklaşık yirmi yıldır yaygın olarak kullanılmaktaydı. Ancak, işveren tarafından sağlanan bir tasarımı yüklenicinin inşa ettiği projelerde, işveren ile yüklenici arasındaki risk paylaşımı konusundaki ciddi tartışmalara sebep olabilmekteydi. En son 1999 yılında yeni versiyonları yayınlanan FIDIC bu ve benzeri nedenlerle uzun bir süreden sonra değişiklik yapma ihtiyacı duymuştur. Örneğin, risk paylaşımının dengeli hale getirilmesi, mühendisin yetkilerinin genişletilmesi ve süre konusundaki belirsizliklerin giderilmesi hususlarında 2017 baskısında ciddi güncelleştirmeler yapılmıştır. Bu yeni baskı ile aşağıdaki hususlar üzerinde güncelleme yapılmıştır.

\subsection{Mühendis}

1999 baskısında Mühendis talimatı verdikten sonraki iki gün içinde Yüklenici (doğrudan veya dolaylı bir) yazılı teyidini alır ve bu teyidi aldıktan sonraki iki gün içinde yazılı bir red ve/veya kabul cevabı verir. Fakat 2017 baskısının Madde 3.5 [Mühendis' in Talimatları]' sinde Yüklenici, bir değişiklik oluşturan, yürürlükteki kanunlara uymayan, işlerin güvenliğini azaltan veya teknik olarak imkânsız olan talimatlar için çalışmaya başlamadan önce, sebepleri ile birlikte Mühendis' e ihbarda bulunacaktır. Mühendis bu ihbarı aldıktan sonraki 7 gün içinde talimatı onaylayan, geri çeviren veya değiştiren bir yanıt vermezse, Mühendis' in bu talimatı iptal edilmiş sayılır (Tablo 1). Aksi halde Yüklenici, Mühendis' in cevabının koşullarına uyacaktır.

\subsection{Yüklenici}

1999 FIDIC' te, yüklenicinin sorumluluklarıyla ifade edilen kati teminat için, bir vade tarihi belirtilmiş ve bu tarihe istinaden, vadenin sona ermesi durumu söz konusuysa, Yüklenici iş bitirme 
belgesi alamayacak, bu belgeyi alabilmesi için iş bitimine kadar gerekli sürede düzeltmesini yapmak zorunda kalacaktı.

Tablo 1. FIDIC Sarı ve Kırmızı Kitap 1999 ve 2017 3.Madde Karşılaştırması [14,15,16,17]

\begin{tabular}{ll|ll}
\hline 3 & \multicolumn{1}{c}{ MÜHENDİS 1999 } & $\mathbf{3}$ & \multicolumn{1}{c}{ MÜHENDİ 2017 } \\
\hline \multirow{3}{*}{ 3.1 } & Mühendisin Görev ve Yetkileri & $\mathbf{3 . 1}$ & Mühendis \\
& & $\mathbf{3 . 2}$ & Mühendisin Görev ve Yetkileri \\
3.2 & Mühendis Tarafindan Yetki Devri & $\mathbf{3 . 3}$ & Mühendisin Temsilcisi \\
$\mathbf{3 . 3}$ & Mühendisin Talimatları & Mühendisin Yetki Devri \\
$\mathbf{3 . 4}$ & Mühendisin Değiştirilmesi & $\mathbf{3 . 5}$ & Mühendisin Talimatları \\
$\mathbf{3 . 5}$ & Tespit Yetkisi & $\mathbf{3 . 6}$ & Mühendisin Değiştirilmesi \\
& & $\mathbf{3 . 7}$ & Anlaşma ve Tespit Yetkisi \\
& & $\mathbf{3 . 8}$ & Toplantılar \\
\hline
\end{tabular}

Ancak, 2017 baskısında ilgili maddede, iş bitimi ifadesi kaldırılmış, zaman tanımı 11.11 [Şantiye Sahasının Temizlenmesi] maddesinin tamamlanmasıyla ilişkilendirilmiştir. Tablo 2'de FIDIC Sarı ve Kırmızı Kitap 1999 ve 2017 4. madde karşılaştırması sunulmaktadır.

Tablo 2. FIDIC Sarı ve Kırmızı Kitap 1999 ve 2017 4.Madde Karşılaştırması [7,8,9,10]

\begin{tabular}{|c|c|c|c|}
\hline 4 & YÜKLENICİ 1999 & 4 & YÜKLENICİ 2017 \\
\hline 4.1 & Yüklenicinin Yükümlülükleri & 4.1 & Yüklenicinin Yükümlülükleri \\
\hline 4.2 & Kati Teminat (Performans Garantisi) & 4.2 & Kati Teminat (Performans Garantisi) \\
\hline 4.3 & Yüklenicinin Değiştirilmesi & 4.3 & Yüklenicinin Değiştirilmesi \\
\hline 4.4 & Alt Yükleniciler & 4.4 & Alt Yükleniciler \\
\hline 4.4 & Alt Yükleniciler & 4.4 & Yüklenicinin Belgeleri \\
\hline 4.5 & Tayin Edilen Yüklenici & 4.5 & Tayin Edilen Yüklenici \\
\hline 4.5 & Altyüklenicilik Anlaşması Haklarının Devri & 4.5 & Eğitim \\
\hline 4.6 & İş Birliği & 4.6 & İş Birliği \\
\hline 4.7 & Ö́n Hazırlıklar & 4.7 & Ön hazırlıklar \\
\hline 4.8 & Güvenlik Prosedürleri & 4.8 & Sağlık ve Güvenlik Yükümlülükleri \\
\hline 4.9 & Kalite Teminatları & 4.9 & Kalite. Yönetim ve Uygunluk Doğrulama Sistemleri \\
\hline 4.10 & Şantiye Sahası Verileri & 4.10 & Saha Verileri Kullanımı \\
\hline 4.11 & Kabul Edilmiş Sözleșme Bedelinin Yeterliliği & 4.11 & Kabul Edilmiş Sözleşme Bedelinin Yeterliliği \\
\hline 4.12 & Öngörülemeyen Fiziksel Koșullar & 4.12 & Öngörülemeyen Fiziksel Koșullar \\
\hline 4.13 & Geçiş/İrtifak Hakları ve Tesisler & 4.13 & Geçiş/İrtifak Hakları ve Tesisler \\
\hline 4.14 & Engellemeden Kaçınma & 4.14 & Engellemeden Kaçınma \\
\hline 4.15 & Erişim Yolları & 4.15 & Erişim Yolları \\
\hline 4.16 & Malzeme Nakliyesi & 4.16 & Malların Nakliyesi \\
\hline 4.17 & Yüklenici Ekipmanları & 4.17 & Yüklenici Ekipmanları \\
\hline 4.18 & Çevrenin Korunumu & 4.18 & Çevrenin Korunması \\
\hline 4.19 & Elektrik, Su, Gaz & 4.19 & Geçici Altyapı Hizmetleri \\
\hline 4.20 & $\begin{array}{l}\text { İșveren Tarafından Temin Edilen Malzemeler ve } \\
\text { İsveren Ekipmanları }\end{array}$ & & \\
\hline 4.21 & İlerleme Raporu & 4.20 & İlerleme Raporu \\
\hline 4.22 & Şantiye Sahasının Güvenliği & 4.21 & Şantiye Sahasının Güvenliği \\
\hline 4.23 & Yüklenicinin Şantiye Sahasındaki Faaliyetleri & 4.22 & Yüklenicinin Şantiye Sahasındaki Faaliyetleri \\
\hline 4.24 & Fosiller & 4.23 & Arkeolojik ve Jeolojik Bulgular \\
\hline
\end{tabular}

\section{3. İşe Başlama, Gecikmeler ve İşin Durdurulması}

Söz konusu uyarılar, 1999 basımındaki 8.3 [İş̧ Programı] maddesinde, Yüklenici’ nin mühendisi uyarmasıyla başlatılan bir süreç olup diğer proje taraflarının uyarısından bahsedilememekte, uyarı yükümlülüğü sadece Yüklenici ve Mühendis arasında işleyen bir prosedür olarak yer almaktadır. 2017 baskısıyla birlikte, problemin sorumluluğunun kime ait olmasının tespit edilmesinden çok, tarafların çoklu katılımıyla olası sorunları çözmek, riskleri minimize etmek ve hak talebi oluşumu engellenmek istenmektedir (Tablo 3).

FIDIC 1999 baskısında, 8.4 [İşin Tamamlanması İçin Süre Uzatımı] maddesi, 2017 baskısı itibariyle 8.5 [İşin Tamamlanması İçin Süre Uzatımı] maddesinde yer almaktadır. Süre uzatımı hükümlerinde dört önemli değişiklik yapılmıştır;

İlk olarak, 1999 basımından farklı olarak Yüklenici' den, bir değiş̧ikliğin neden olduğu bir gecikme için süre uzatımı talebini ayrı olarak bildirmesi gerekli değildir (bu bildirim 13.3'deki Değişiklikler 
maddesine eklenmiştir). İkincisi, "istisnai derecede olumsuz iklim koşulları" için gecikme, "iklimsel verilere ilişkin olarak öngörülemeyen" olarak nitelendirilmiştir. Yeni düzenlemeyle, iklim koşulları "öngörülemeyen olumsuz iklim değişiklikleri, içinde bulunduğu coğrafik bölge itibariyle, ülkenin meteoroloji kayıtlarında daha önce benzerine rastlanmamış ve kayıt altına alınmamış, hiçbir şekilde öngörülmesi mümkün olmayan olağandışı olumsuz durumlar" olarak tarif edilmiştir. Üçüncüsü, Yüklenici' nin gecikmesi, tahmini bir miktarın \%10'undan daha fazla bir artıştan kaynaklanması halinde süre uzatımına açık bir hakkı olmasıdır. Bu değişiklik sadece Kırmızı Kitap özelindedir. Dördüncüsü ise, taraflardan, Özel Hükümler aracılığıyla eşzamanlı gecikmeyle ilgili kuralları ve prosedürleri oluşturmaları istenmektedir.

Tablo 3. FIDIC Sarı ve Kırmızı Kitap 1999 ve 2017 8. Madde Karşılaştırması [7,8,9,10]

\begin{tabular}{|c|c|c|c|c|}
\hline 8 & $\begin{array}{l}\text { İŞE BAŞLAMA, GECÍKMELER ve } \\
\text { ALMA } 1999\end{array}$ & ASKIYA & 8 & $\begin{array}{lccc}\text { İŞE } & \text { BAŞLAMA, GECİKMELER } & \text { ve } & \text { İşín } \\
\text { DURDURULMASI } 2017 & & \end{array}$ \\
\hline 8.1 & İşin Başlaması & & 8.1 & İşin Başlaması \\
\hline 8.2 & Tamamlanma Süresi & & 8.2 & Tamamlanma Süresi \\
\hline 8.3 & İş Programı & & 8.3 & İş Programı \\
\hline & & & 8.4 & Tarafların Birbirini Erkenden Uyarması \\
\hline 8.4 & İșin Tamamlanması İçin Süre Uzatımı & & 8.5 & İșin Tamamlanması İçin Süre Uzatımı \\
\hline 8.5 & Otoriteler Sebebiyle Yaşanan Gecikmeler & & 8.6 & Yetkili Makamların Neden Olduğu Gecikmeler \\
\hline 8.6 & İlerleme Oranı & & 8.7 & İlerleme Oranı \\
\hline 8.7 & Gecikme Zararları & & 8.8 & Gecikme Zararları \\
\hline 8.8 & İşin Durdurulması & & 8.9 & İşverenin İşi Durdurulması \\
\hline 8.9 & İşin Durdurulmasının Sonuçları & & 8.10 & İşverenin İşi Durdurmasının Sonuçları \\
\hline 8.10 & $\begin{array}{l}\text { İşveren Tarafindan İşin Durdurulması Sonrası } \\
\text { Malzeme Ödemesi }\end{array}$ & 1 Tesis ve & 8.11 & $\begin{array}{l}\text { İşveren Tarafından İşin Durulması Sonrası Tesis ve } \\
\text { Malzeme Ödemesi }\end{array}$ \\
\hline 8.11 & Uzun Süreli Olarak İşin Durdurulması & & 8.12 & Uzun Süreli Olarak İşin Durdurulması \\
\hline 8.12 & İşe Yeniden Başlama & & 8.13 & İşe Yeniden Başlama \\
\hline
\end{tabular}

\section{4. İşin Devralınmasından Sonra Ortaya Çıkan Kusurlar}

1999 baskısında, söz konusu süreç ve kusurun, bildirim süresinde ortaya çıkmış olma ayrıntısına yer verilmemiştir. Buna göre, kusur bildirim süresinde ortaya çıkan bir kusur ve zararın giderilmesi için süreç şu şekilde işlemektedir; Öncelikle, Mühendis tarafindan yükleniciye ihbarda bulunulur. Yüklenici ve İşveren personelinden biri kusurlu işi yerinde denetler. Yapılan incelemeler sonucunda kusurun giderilmesi için Yüklenici tarafından öneride bulunulur.

Tablo 4. FIDIC Sarı ve Kırmızı Kitap 1999 ve 2017 11.Madde Karșılaștırması [7,8,9,10]

\begin{tabular}{|c|c|c|c|}
\hline 11 & HASAR SORUMLULUĞU & 11 & $\begin{array}{l}\text { İŞIN DEVRALINMASINDAN SONRA ORTAYA } \\
\text { ÇIKAN KUSURLAR }\end{array}$ \\
\hline 11.1 & Eksik İşlerin Tamamlanması ve Kusurların Giderilmesi & 11.1 & Eksik İşlerin Tamamlanması ve Kusurların Giderilmesi \\
\hline 11.2 & Kusurların Giderilme Maliyeti & 11.2 & Kusurların Giderilme Maliyeti \\
\hline 11.3 & Kusurların İhbar Süresinin Uzatılması & 11.3 & Kusurların İhbar Süresinin Uzatılması \\
\hline 11.4 & Kusurların Giderilememesi & 11.4 & Kusurların Giderilememesi \\
\hline 11.5 & $\begin{array}{l}\text { Kusurlu İşlerin Şantiye Dışında Çözülmesi (tamir için } \\
\text { şantiye dışına çıkarılması) }\end{array}$ & 11.5 & $\begin{array}{l}\text { Kusurlu İşlerin Şantiye Dışında Çözülmesi (tamir için } \\
\text { şantiye dışına çıkarılması) }\end{array}$ \\
\hline 11.6 & İlave Testler & 11.6 & Kusurlar Giderildikten Sonra İlave Testlerin Yapılması \\
\hline 11.7 & İşin Devralınmasından Sonra Erişim Hakkı & 11.7 & İşin Devralınmasından Sonra Erişim Hakkı \\
\hline 11.8 & Yüklenici Tetkik ve Teftişi & 11.8 & Yüklenicinin Tetkik ve Teftişi \\
\hline 11.9 & Performans Sertifikası (İş Bitirme Belgesi) & 11.9 & Performans Sertifikası (İş Bitirme Belgesi) \\
\hline 11.10 & Yerine Getirilmemiş Yükümlülükler & 11.10 & Yerine Getirilmemiş Yükümlülükler \\
\hline 11.11 & Şantiye Sahasının Temizlenmesi & 11.11 & Şantiye Sahasının Temizlenmesi \\
\hline
\end{tabular}

Yüklenici tarafından yapılan öneriye, Mühendis tarafından 14 gün içerisinde cevap verilmezse, Yüklenici önerisini aynen uygular. 1999 baskısında, Mühendis' in cevabına ilişkin azami süreden bahsedilmemiştir (Tablo 4). Söz konusu detay yeni baskı itibariyle sözleşme maddelerine eklenmiştir. 1999 basımı, gizli kusur yükümlülüğü konusunda sessiz kalırken 2017 baskısı 11.10 [Yerine Getirilmemiş Yükümlülükler] uyarınca, Yüklenici' nin şantiyedeki gizli kusurlara karşı söz konusundaki yükümlülüğü, kanunen yasaklanmadıkça (veya herhangi bir dolandırıcılık, ağır ihmal, kasitlı temerrüt veya suistimal), hata bildirimi süresinin (DNP) bitiminden iki yıl sonra sona erer. 


\subsection{Değişiklikler ve Düzeltmeler}

1999 yılı basımı FIDIC sözleşmelerinde madde 13.4'te söz edilen [Kabul edilen para cinsinden ödeme yapılması] maddesi yeni basımda kaldırılmış ve ödememelerde geçerli olan maddeler sırasıyla madde 13.5 [Ödemesi Yevmiye Usulüne Göre Yapılan İşler (Gündelik İşler)], madde 13.6 [Yasalardaki Değişiklerden Dolayı Yapılan Düzeltmeler] ve madde 13.7 [Maliyetlerdeki Değişiklerden Dolayı Yapılan Düzeltmeler] olmuştur.

Tablo 5. FIDIC Sarı ve Kırmızı Kitap 1999 ve 2017 13.Madde Karşılaştırması [7,8,9,10]

\begin{tabular}{|c|c|c|c|c|}
\hline 13 & DEĞIŞiKLİKLER VE DÜZELTMELER 19 & & 13 & DEĞİŞiKLİKLER VE DÜZELTMELER 2017 \\
\hline 13.1 & Değişiklik Hakk1 & & 13.1 & Değişiklik Hakk1 \\
\hline 13.2 & Değer Mühendisliği & & 13.2 & Değer Mühendisliği \\
\hline 13.3 & Değișiklik Prosedürü & & 13.3 & Değişiklik Prosedürü \\
\hline 13.4 & Kabul Edilen Para Cinsinden Ödeme Yapılması & & & \\
\hline 13.5 & Geçici/Şartlı Tutar & & 13.4 & Geçici Meblağ \\
\hline 13.6 & Yevmiye Usulü İşler & & 13.5 & $\begin{array}{l}\text { Ödemesi Yevmiye Usulüne Göre Yapılan İşler (Gündelik } \\
\text { İşler) }\end{array}$ \\
\hline 13.7 & $\begin{array}{l}\text { Yönetmeliklerdeki Değişiklikl } \\
\text { Düzeltmeler }\end{array}$ & Yapilan & 13.6 & Yasalardaki Değişiklerden Dolayı Yapılan Düzeltmeler \\
\hline 13.8 & $\begin{array}{l}\text { Maliyetlerdeki Değişiklikler } \quad \text { Sebebiyle } \\
\text { Düzeltmeler }\end{array}$ & Yapılan & 13.7 & Maliyetlerdeki Değişiklerden Dolayı Yapılan Düzeltmeler \\
\hline
\end{tabular}

\subsection{Sözleşme Bedeli ve Ödemeler}

Daha önceki basımda Yüklenici tarafından Mühendis' e verilmesi beklenen ve sadece 6 kopya olarak ifade edilen başvuru çizelgesi, yeni basımda daha detaylı bir ifadeyle, 1 basılı kopya baskı, 1 dijital baskı ve sözleşmede belirtilmişse, sözleşmede belirtildiği şekli ve sayısıyla Mühendis' e teslim edileceği vurgulanmıştır.

Tablo 6. FIDIC Sarı ve Kırmızı Kitap 1999 ve 2017 14.Madde Karşılaştırması [7,8,9,10]

\begin{tabular}{llll}
\hline $\mathbf{1 4}$ & SÖZLEŞME BEDELİ VE ÖDEMELER 1999 & $\mathbf{1 4}$ & SÖZLEŞME BEDELI VE ÖDEMELER 2017 \\
\hline $\mathbf{1 4 . 1}$ & Sözleşme Bedeli & $\mathbf{1 4 . 1}$ & Sözleşme Bedeli \\
$\mathbf{1 4 . 2}$ & Ön Ödeme & $\mathbf{1 4 . 2}$ & Avans Ödemesi \\
$\mathbf{1 4 . 3}$ & Ara Ödeme Sertifika Başvurusu & $\mathbf{1 4 . 3}$ & Ara Ödeme (Hakediş) Başvurusu \\
$\mathbf{1 4 . 4}$ & Ödeme Takvimi & $\mathbf{1 4 . 4}$ & Ödeme Takvimi \\
$\mathbf{1 4 . 5}$ & İşte Kullanılan Tesis ve Malzemeler & $\mathbf{1 4 . 5}$ & İşte Kullanılan Tesis ve Malzemeler \\
$\mathbf{1 4 . 6}$ & Ara Ödeme (Hakediş) Sertifikası & $\mathbf{1 4 . 6}$ & Ara Ödeme (Hakediş) Sertifikası \\
$\mathbf{1 4 . 7}$ & Ödemeler & $\mathbf{1 4 . 7}$ & Ödemeler \\
$\mathbf{1 4 . 8}$ & Ödemelerde Gecikme & $\mathbf{1 4 . 8}$ & Ödemelerde Gecikme \\
$\mathbf{1 4 . 9}$ & Nakti Teminat Kesintilerinin Ödemesi & $\mathbf{1 4 . 9}$ & Nakit Teminat Kesintilerinin İadesi \\
$\mathbf{1 4 . 1 0}$ & Kesin Hesap & $\mathbf{1 4 . 1 0}$ & Geçici Kabul \\
$\mathbf{1 4 . 1 1}$ & Kesin Hakediş Sertifikası Başvurusu & $\mathbf{1 4 . 1 1}$ & Kesin Hesap \\
$\mathbf{1 4 . 1 2}$ & İbra & $\mathbf{1 4 . 1 2}$ & İbra \\
$\mathbf{1 4 . 1 3}$ & Kesin Ödeme Sertifikasının Verilmesi & $\mathbf{1 4 . 1 3}$ & Kesin Ödeme Sertifikasının Verilmesi \\
$\mathbf{1 4 . 1 4}$ & İşverenin Sorumluluğunun Sona Ermesi & $\mathbf{1 4 . 1 4}$ & İşverenin Sorumluluğunun Sona Ermesi \\
$\mathbf{1 4 . 1 5}$ & Ödeme Yapılacak Para Birimi & $\mathbf{1 4 . 1 5}$ & Ödeme de Kullanıllacak Para Birimi \\
\hline
\end{tabular}

\section{7. İşveren Tarafından Fesih}

15. [İşveren Tarafindan Fesih] maddesine aşağıdaki tabloda görülebileceği gibi 2 alt başlık daha eklenmiştir. 15.2.1. [Fesih], maddesinde feshin gerçekleşeceği tarih ve prosedür açik bir dille ifade edilmiştir. Buna göre; Yüklenici işveren tarafından yapılan temerrüdün giderilmesi ihbarını aldıktan sonra 14 gün içerisinde, ihbarda açıklanan durumları ortadan kaldıramıyorsa, İşveren tarafından ikinci bir ihbar gönderilerek fesih işlemi gerçekleştirilir. Yüklenici' nin ikinci ihbarı aldığı tarih, fesih tarihi olarak kabul edilir. 1999 basımında, fesih için 2. Bir ihbar bildiriminin yapılmasından ve fesih tarihinden söz edilmemektedir.

15.3 [Yüklenici Hatası Kaynaklı Fesih Sonrası Değerlendirme] maddesinin 1999 baskısına göre daha kapsamlı olarak anlatılmıştır. Fesih sonrası, Yüklenici' nin fesih gerçekleşene kadar, sözleşme gereğince yaptığı işlerin, malların, Yüklenici belgelerinin ve sözleşme hükümlerine göre yapılmış 
işler karşılığında Yüklenici' ye ödenmesi gereken diğer tutarların değerleri tespit edilmeli ve Yüklenici'yle anlaşmaya varılmalıdır. 15.5. İşveren Yararına Fesih, 15.6 İşveren Yararına Fesih İtibariyle Değerlendirme, 15.7 İşveren Yararına Fesih Sonrası Ödeme maddeleriyle, 1999 baskısında yer alan 15.5 İşverenin Fesih Hakkı maddesinde yer alan gereklilikler daha kapsamlı olarak açıklanmaktadır. Buna göre, Fesih sonrası yüklenicin ve işverenin hakları, fesih sonrası ödeme bedeli değerlendirme ve fesih itibariyle yükleniciye yapılması gereken ödeme tarihi daha net bir şekilde ortaya koyulmuş ve fesihle ilgili maddelere "yararına" tanımı eklenerek İşveren tarafından yapılacak olası suiistimallerin önüne geçilmesi amaçlanmıştır.

Tablo 7. FIDIC Sarı ve Kırmızı Kitap 1999 ve 2017 15.Madde Karşılaştırması [7,8,9,10]

\begin{tabular}{llll}
\hline $\mathbf{1 5}$ & İşVEREN TARAFINDAN FESİH 1999 & $\mathbf{1 5}$ & İşVEREN TARAFINDAN FESİH 2017 \\
\hline $\mathbf{1 5 . 1}$ & Temerrüdün Giderilmesi İhbarı & $\mathbf{1 5 . 1}$ & Temerrüdün Giderilmesi İhbarı \\
$\mathbf{1 5 . 2}$ & İşveren Tarafından Fesih & $\mathbf{1 5 . 2}$ & Yüklenici Hatası Kaynaklı Fesih \\
$\mathbf{1 5 . 3}$ & Fesih Tarihinin Değerlendirilmesi & $\mathbf{1 5 . 3}$ & Yüklenici Hatası Kaynaklı Fesih Sonrası Değerlendirme \\
$\mathbf{1 5 . 4}$ & Fesih Sonrası Ödeme & $\mathbf{1 5 . 4}$ & Yüklenici Hatası Kaynaklı Fesih Sonrası Ödeme \\
$\mathbf{1 5 . 5}$ & İşverenin Fesih Hakkı & $\mathbf{1 5 . 5}$ & İşveren Yararına Fesih \\
& & $\mathbf{1 5 . 6}$ & İșveren Yararına Fesih İtibariyle Değerlendirme \\
& & $\mathbf{1 5 . 7}$ & İşeren Yararına Fesih Sonrası Ödeme \\
\hline
\end{tabular}

\section{8 "Yüklenici Tarafından Fesih ve İşin Durdurulması"}

1999 baskısında Yüklenici’ nin işe devam etme şartı, İşveren’ le ilişkilendirilmeyip, Yüklenici’ nin ödeme alması durumunda işe devam edeceği belirtilmiştir. 1999 tarihli basımlarda, Madde 16.2 [Yüklenici Tarafından Fesih] (d), "İşveren Sözleşme ile yükümlülüklerini büyük ölçüde yerine getiremezse", Yüklenici' nin sözleşmeyi feshetme hakkına sahip olduğunu belirtmiştir. 2017 basımlarında, 16.2.1 [ihbar] (e), Yüklenici' nin 'Işveren, büyük ölçüde yerine getirmekte başarısızdır ve bu tür bir başarısızlık, İşveren' in Sözleşme kapsamındaki yükümlülüklerini önemli bir ihlal teşkil eder' durumlarında sona erdirme niyetine dair bir bildirimde bulunma hakkına sahip olduğunu belirtir.

16.2.1 [ihbar] maddesi (j), 1999 tarihli baskıda yolsuzluk ödemeleri için fesih, vb. sadece işveren tarafından sahip olunan bir haktır. 2017 baskısı ise, her iki tarafa da bu hakkı vermiştir. 1999 basımında, Yüklenici feshi için gerekli olan şart ve durumlardan herhangi birisinin meydana gelmesi durumunda, Yüklenici 14 gün önceden İşveren' e ihbarda bulunmak kaydiyla sözleşmeyi fesih edebiliyorken, 2017' de sözleşmenin fesih ihbarından önce bir fesih daha yayınlayarak, Yüklenici' nin ihbarda yer alan olumsuzlukları 14 gün içerisinde ortadan kaldırması istenmektedir. İşveren ihbarda yer alan olumsuzlukları kendisine tanınan sürede ortadan kaldırmadığı takdirde, Yüklenici sözleşmenin feshi için ihbarda bulunma hakkına sahip olur. (2017 FIDIC 16.2.2 Fesih maddesi)

Tablo 8. FIDIC Sarı ve Kırmızı Kitap 1999 ve 2017 16.Madde Karşılaştırması [7,8,9,10]

\begin{tabular}{|c|c|c|c|c|}
\hline 16 & $\begin{array}{l}\text { YÜKLENICI TARAFINDAN FESİH VE İŞiN } \\
\text { DURDURULMASI } 1999\end{array}$ & 16 & $\begin{array}{l}\text { YÜKLENICI TARAFINDAN FESİH } \\
\text { DURDURULMASI } 2017\end{array}$ & VE İşíN \\
\hline 16.1 & Yüklenicinin Tarafindan İşin Durdurulması & 16.1 & Yüklenici Tarafindan İşin Durdurulması & \\
\hline 16.2 & Yüklenici Tarafından Fesih & 16.2 & Yüklenici Tarafindan Fesih & \\
\hline 16.3 & İşin Durması ve Yüklenici Ekipmanlarının Kaldırılması & 16.3 & Fesih Sonrası Yüklenicinin Yükümlülükleri & \\
\hline 16.4 & Fesih Halinde Ödeme & 16.4 & Yüklenici Feshi Sonrası Ödemeler & \\
\hline
\end{tabular}

\section{9 İşveren ve Yüklenicinin Hak Talepleri}

14 gün içinde böyle bir bildirimde bulunulmaması durumunda, talep bildirimi geçerli bir bildirim olarak kabul edilecektir. Bu, 1999 baskısında bulunmayan Mühendis' e önemli derecede daha fazla sorumluluk verir.

Tam olarak detaylı bir talep sunma yükümlülüğü 1999 baskısından bu yana değişmemiş olsa da, “tam ayrıntılı hak talebi” için olan eski 42 günlük süre 84 güne yükseltilmiştir. Talepte bulunan 
taraf, 84 gün içerisinde talebin yasal ve sözleşmesel bir dayanakla birlikte bir bildirimde bulunamazsa, talepte bulunma süresi sona ermiş sayılır. Mühendis, süresi dolduktan sonra yapılan talepler için, talebi sunduğu tarihten itibaren 14 gün içinde talep eden tarafa bu konuda bir ihbarda bulunabilir. Mühendis 14 günlük süre içinde böyle bir ihbarda bulunmazsa, talep bildirimi geçerli bir ihbar olarak kabul edilir.

Tablo 9. FIDIC Sarı ve Kırmızı Kitap 1999 ve 2017 20.Madde Karşılaştırması [7,8,9,10]

\begin{tabular}{|c|c|c|c|}
\hline 20 & $\begin{array}{l}\text { HAK TALEPLERİ, ANLAŞMAZLIKLAR VE } \\
\text { TAHKIM } 1999\end{array}$ & 20 & $\begin{array}{l}\text { İŞVEREN ve YÜKLENICİIIN HAK TALEPLERİ } \\
2017\end{array}$ \\
\hline 20.1 & Yüklenicinin Hak Talepleri & $\begin{array}{l}20.1 \\
20.2\end{array}$ & $\begin{array}{l}\text { Hak Talepleri } \\
\text { Ödeme ve Süre Uzatımı Hak Talepleri }\end{array}$ \\
\hline
\end{tabular}

\subsection{Uyuşmazlıklar ve Tahkim}

Yeni baskıda "uyuşmazlıklar", 1.1 [Tanımlar] maddesinin 1.1.29 numaralı alt maddesinde açık bir şekilde ifade edilmekte olup, 1999 basımında tanımlar maddesinde alt başlık olarak, uyuşmazlık tanımına yer verilmemiştir. 1999 basımında, 20. [Madde Hak Talepleri, Uyuşmazlık ve Tahkim] maddesi altında, sadece uyuşmazlık çözüm kurullarıyla ilgili maddelerde uyuşmazlık konusuna üstü kapalı olarak değinilmiştir. Tanımı açık ve net bir şekilde yapılmamış olan "uyuşmazlık" kavramının, daha ne olduğu karşı tarafa net bir şekilde anlatılmadan, farklı konu başlıkları içerisinde geçiriliyor olması, sözleşme idaresinde ve inşaat sırasında belirsizliklerin ve belirli risklerin ortaya çıkmasına sebebiyet verebilecekken, 2017 baskısındaki haliyle olası belirsizlikler ortadan kaldırılmıştır.

Tablo 10. FIDIC Sarı ve Kırmızı Kitap 1999 ve 2017 21.Madde Karşılaştırması [7,8,9,10]

\begin{tabular}{|c|c|c|c|}
\hline 20 & $\begin{array}{l}\text { HAK TALEPLERİ, ANLAŞMAZLIKLAR VE } \\
\text { TAHKİM } 1999\end{array}$ & 21 & UYUŞMAZLIKLAR ve TAHKİM 2017 \\
\hline 20.2 & Uyuşmazlık Çözüm Kurulunun Oluşturulması & 21.1 & $\begin{array}{l}\text { DAB (Uyuşmazlıktan Kaçınma ve Çözüm Kurulu) } \\
\text { Üyelerinin Atanması }\end{array}$ \\
\hline \multirow[t]{2}{*}{20.3} & $\begin{array}{l}\text { Uyuşmazlık Çözüm Kurulu Üzerine Anlaşma } \\
\text { Sağlanamaması }\end{array}$ & 21.2 & $\begin{array}{l}\text { DAB (Uyuşmazlıktan Kaçınma ve Çözüm Kurulu) } \\
\text { Üyelerinin Atanamaması }\end{array}$ \\
\hline & & 21.3 & Uyuşmazlıklardan Kaçınma \\
\hline 20.4 & $\begin{array}{l}\text { Uyuşmazlık Çözüm Kurulu Kararının Geçerli } \\
\text { Olması }\end{array}$ & 21.4 & $\begin{array}{l}\text { DAB (Uyuşmazlıktan Kaçınma ve Çözüm Kurulu) } \\
\text { Kararının Geçerli Olması }\end{array}$ \\
\hline 20.5 & Dostane Çözüm & 21.5 & Dostane Çözüm \\
\hline 20.6 & Tahkim & 21.6 & Tahkim \\
\hline 20.7 & Uyuşmazlık Çözüm Kurulu Kararına Uyulmaması & 21.7 & $\begin{array}{l}\text { DAB (Uyuşmazlıktan Kaçınma ve Çözüm Kurulu) } \\
\text { Kararına Uyulamaması }\end{array}$ \\
\hline 20.8 & $\begin{array}{l}\text { Uyuşmazlık Çözüm Kurulu Görevinin Sona Ermiş } \\
\text { Olması }\end{array}$ & 21.8 & $\begin{array}{l}\text { DAB (Uyuşmazlıktan Kaçınma ve Çözüm Kurulu)'ın Hazır } \\
\text { ve Nazır Olmaması veya Teşkil Edilmemesi } 1999\end{array}$ \\
\hline
\end{tabular}

Kitabın 1999 baskısında yer alan ve olası bir uyuşmazlık durumunda başvurulacak Uyuşmazlık Çözüm Kurulu, 2017 baskısı itibariyle "Uyuşmazlık tan Kaçınma ve Çözüm Kurulu” olarak adlandırılarak, söz konusu kurula, taraflar arasında ortaya çıkan probleme gerekli zamanda gerekli müdahaleyi yapıp, problemin uyuşmazlık haline gelmeden çözülmesi sorumluluğu yüklenmiştir. 2017 baskısında uyuşmazlıktan kaçınma konusundaki vurguyu yansıtılarak tanıtılan DAB' ye, bir dizi önemli prosedür getirmiştir. Öncelikle, 1999 baskısının 20.2 [Uyuşmazlık Çözüm Kurulunun Oluşturulmas1] maddesinde, tarafların 'Teklif Ekinde belirtilen tarihe kadar birlikte bir DAB atacağını' belirtirken, 2017 baskısının 21.1 [DAB üyelerinin Atanması] maddesinde, Taraflar aksi kararlaştırmadıkça, DAB üyeleri, Yüklenici Kabul Mektubunu aldıktan sonraki 28 gün içinde atanacaktır. Ayrıca İstifa, fesih ve yeni atamalar için de ayrıntılı prosedürler vardır. Buna göre DAB 3 kişilik bir ekipten oluşmaktadır. Sözleşme taraflarından her biri, birer üyeyi seçmek suretiyle 2 üyeyi belirler. 3. Üye ise her iki tarafın da (işveren ve yüklenici) ortak onay verdiği bir üye olup, DAB içerisinde başkan olarak görev yapar. 
1999 tarihli basımların 20.5 [Dostane Çözüm] maddesinde olduğu gibi, tahkim kararına gidilmeden dostane çözüm için 2017 basımının 21.5 [Dostane Çözüm] maddesinde hüküm verilmiştir. Ancak dostane çözüm için süre 56 günden 28 güne düşürülerek, olası bir anlaşmazlığa daha hızlı sürede çözüm üretilmesi ve inşaat iş programındaki olası aksaklıkların minimize edilmesi amaçlanmıştır.

\section{Sonuç ve Öneriler}

FIDIC sözleşmeleri, büyük önem ve değer taşıyan özel sözleşmelerdir ve bu sözleşmelerin çoğu yollar, demiryolları, köprüler, gayrimenkuller ve havaalanları gibi büyük ve karmaşık mühendislik projeleri sözleşmeleridir [18,19]. Karmaşık yapıları nedeniyle inşaat sözleşmeleri nispeten hantaldır ve pratikte anlaşılması zordur. $\mathrm{Bu}$ nedenle, FIDIC model sözleşmelerini örnek olarak alarak, karmaşı inşaat sözleşmesi belgelerini daha iyi anlamak ve inşaat sözleşmelerinin tasarım özelliklerinin farklı formlarını gözlemlemek ilgi çekici ve pratiktir [20].

Yapılan değerlendirmeler sonucunda, yurtdışı inşaat sektöründe ve günümüz uygulamalarında yaygın olarak kullanılan standart sözleşme formlarından FIDIC sözleşme formunun kırmızı ve sarı kitap özelinde, 1999 ile 2017 baskısı arasındaki farklılık ve benzerlikler ortaya konulmaya çalışılmıştır. Buradan hareketle inşaat sektörünce yayınlanmış standart sözleşme formu olan 2017 FIDIC hükümlerinin, içerik ve uygulama açısından 1999 FIDIC hükümlerine nazaran oldukça kesin, işlevsel ve katılımcıların daha fazla baskılandığı sonucuna varılmıştır. Örneğin, 2017 yılında güncellenen FIDIC Kırmızı Kitap'ta tarafların ihtilafi resmi yargıya taşımadan önce başvuru yapabilecekleri bağımsız, alanında uzman ve tecrübeli bir mühendis, İhtilafı Giderme/Önleme Heyeti ve tahkim yolunun varlığ 1 dikkat çekmektedir. Yine, "Mühendis" in karar verme ve bildirme süreleri bölüm 3.1'de anlatıldığı gibi kesin bir şekilde belirlenmiş ve karmaşaya neden olmayacak şekilde açık ifade edilmiştir. Bir başka örnek ise bölüm 3.4'te açıklanan süre uzatımı hükümlerinde yapılan açıklamalar ya da FIDIC 2017 [20.2] maddesinde açıklanan Ödeme ve Süre Uzatımı Hak Talebi için getirilmiş ve herhangi bir belirsizliğe yol açmamak için verilen net açıklamalardır.

Ayrıca, 2017 baskısında Mühendis’ in rolü önemli ölçüde arttırılmış, ihbar süreçleri ve zaman çizelgelerinde önemli değişiklikler olmuştur. Ek olarak, DAB'a ve anlaşmazlıklardan kaçınmaya daha fazla önem verilmiştir. Kitabın yeni baskısıyla birlikte, ek proje yönetim araçlarının tanımlanması (tarafların birbirini erkenden uyarması, ihbar bildirimleri, kalite, yönetim ve uygunluk doğrulama sistemleri, dokümantasyon çeşitliği vb...) ve var olan görev ve tanımların iyileştirilmesi yoluyla, taraflar arasında daha bütüncül ve iletişime dayalı bir proje yönetimi oluşturulmaya çalışılmıştır. Ancak, yüksek oranda kural koyucu prosedürlerin getirilmesi, bazı kullanıcıların görmek istediği şey olmayabilir. FIDIC' in 2017 baskısıyla birlikte, sözleşme dilinde ve işleyişte yüksek oranda kural koyucu prosedürlerin getirildiği gözlemlenmiştir. Bu haliyle anlam karmaşası ve belirsizlikler sebebiyle ortaya çıkabilecek riskler minimize edilirken, diğer taraftan da yüksek oranda kural koyucu prosedürlerin getirilmesi, işleyişin zorlaşması ve sonuca ulaşmadaki sürecin uzaması anlamına gelebilir. $\mathrm{Bu}$ çalışma ile Türk müteahhitlik sektöründe çalışıp, uluslararası projelerde yer almayı hedefleyen yüklenicilere ya da hale hazırda bu tip tecrübesi olan inşaat firmalarına en sık kullanılan FIDIC sözleşmelerindeki son gelişmeleri ve farklılıkları sunarak yol gösterilmek istenmiştir. Çünkü, bu çalışma yürütülürken yapılan literatür araştırmasında, FIDIC Standart sözleşme dokümanlarını detaylı olarak anlatan Türkçe kaynakların yok denecek kadar az olduğu gözlenmiştir. Bu çalışmayla, FIDIC' le ilgili Türkçe kaynakların artırılması ve FIDIC sözleşmeleri özelinde Hak Talepleri, Uyuşmazlık ve Tahkim (Claims, Disputes and Arbitration), Yüklenici Tetkik ve Teftişi (Contractor to Search), İşin Devralınmasından Sonra Erişim Hakkı (Right of Access) ya da Dostane Çözüm (Amicable Settlement) gibi terimlerin Türkçe karşılıklarının oluşturulması hedeflenmiştir. 


\section{Kaynaklar}

[1]. Keleş, A.E., Keleș, M.K., İnşaat Sektöründe Kullanımı Artan Bilgisayar Yazılımları ve Bilgi Teknolojilerinin İrdelenmesi. El-Cezeri Journal of Science and Engineering. 2018;5(2):610-7.

[2]. Alpkökin, P., Türk inşaat sektöründe uyuşmazlık çözüm kurulu uygulamaları. Karaelmas Science and Engineering Journal, 2017, 7(2), 674-683.

[3]. Booen, P. L., The FIDIC contracts guide, Federation Internationale Des Ingineurs Conseile, Genève, 2000.

[4]. Bunni, N. G. The FIDIC forms of contract, Wiley-Blackwell, West Sussex, U.K., 2005.

[5]. El-Adaway, I., Fawzy, S., Burrell, H., \& Akroush, N., Studying payment provisions under national and international standard forms of contracts. Journal of Legal Affairs and Dispute Resolution in Engineering and Construction, 2017, 9(2), 04516011.

[6]. Sanvido, Victor Ernest, and Mark Konchar. Selecting project delivery systems: Comparing design-build, design-bid-build and construction management at risk. Project Delivery Institute, 1999.

[7]. Glover, J., FIDIC: An overview. The latest developments, compari- sons, claims and force majeure. Fenwick Elliott, London: Construction Law Summer School, 2007.

[8]. Hillig, J.-B., D. Dan-Asabe, S. Donyavi, O. Dursun, and A. Thampuratty., FIDIC's Red Book 1999 edition: A study review. Proc. Inst. Civ. Eng. Manage. Procurement Law, 2010, 163 (3): 129-133. https://doi .org/10.1680/mpal.2010.163.3.129.

[9]. Shnookal, T., and Charrett, D., Standard form contracting; the role for FIDIC contracts domestically and internationally.” In Proc., Society of Construction Law Conf. 30, 2010, Sydney, NSW: Melbourne TEC Chambers.

[10]. Sanni, A. G., Adebiyi, O. J., \& Okorie, N. V., Residual Risks Of Payment Provisions In FIDIC And JCT Conditions: A Quantity Surveyor's View. Open Journal of Physical Science (ISSN: 2734-2123), 2020, 1(1), 26-40.

[11]. Wang, R., Lu, W., \& Wei, Y., Owners' use of contract-based power in construction project transactions: restrictions from process specificity and uncertainty. Construction Management and Economics, 2020, 1-16.

[12]. Hardjomuljadi, S., Use of Dispute Avoidance and Adjudication Boards. Journal of Legal Affairs and Dispute Resolution in Engineering and Construction, 2020, 12(4), 03720004.

[13]. FIDIC, Conditions of Contract for Construction, 1. Edition, 1999.

[14]. FIDIC, Conditions of Contract for Plant \& Design Build, 1. Edition, 1999.

[15]. FIDIC, (2017) Conditions of Contract for Construction, 2. Edition.

[16]. FIDIC, (2017) Conditions of Contract for Plant \& Design Build, 2. Edition.

[17]. Omran, M. E. A Review about FIDIC Contracts in Saudi Arabia. Indian Journal of Science and Technology, 2019, 12- 36.

[18]. Gunduz, M., \& Elsherbeny, H. A., Operational framework for managing construction-contract administration practitioners' perspective through modified Delphi method. Journal of Construction Engineering and Management, 2020, 146(3), 04019110.

[19]. Chen, Y., Wang, W., Zhang, S., \& You, J., Understanding the multiple functions of construction contracts: the anatomy of FIDIC model contracts. Construction Management and Economics, 2018, 36(8), 472-485.

[20]. Sadek, S. M. A., Managing standard construction contractual forms modifications in the Middle East-overview and recommendations. Ph.D. dissertation, School of Built Environment, Univ. of Salford, 2016. 